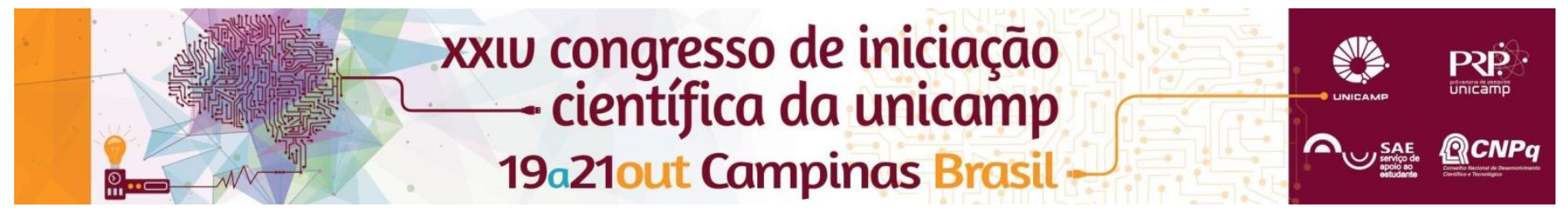

\title{
Obtenção de Ésteres Aromáticos usando imobilizado híbrido PÓS-PVA lipase de Burkholderia cepacia.
}

\author{
Victor A. B. Campos*, Telma T. Franco, Giovana S. Padilha.
}

\section{Resumo}

Este trabalho apresenta o estudo dos parâmetros para a obtenção dos seguintes ésteres aromáticos: acetato de isoamila (Al), acetato de hexila (AH) e valerato de etila (VE). Para obtenção dos ésteres, foi utilizado lipase comercial de Burkholderia cepacia imobilizada em suporte híbrido PÓS-PVA (Polissiloxano-álcool polivinílico) na presença de solventes orgânicos.

\section{Palavras-chave:}

Ésteres Aromáticos, Lipase, Burkholderia cepacia, PÓS-PVA.

\section{Introdução}

A esterificação é de fundamental importância industrial tendo diversos papéis desde solventes, polímeros e plastificantes abrangindo também a produção de fármacos, herbicidas e pesticidas ${ }^{1}$.

A busca por rotas sintéticas na produção de ésteres tem se tornado cada vez mais frequente ${ }^{2}$ já que a obtenção via extração natural apresenta alto custo e produto irrisório ${ }^{3}$.

Um obstáculo da via química é a velocidade de reação. Diversos catalisadores são testados para obter o maior custo-benefício possível. Uma alternativa que vem ganhado destaque são os catalisadores, dentre eles, a lipase ${ }^{4}$.

Para garantir máxima eficiência das lipases empregadas nesta rota sintética dos ésteres, utiliza-se a imobilização das enzimas adsorvidas no interior ou superfície de materias denominados suportes.

Além disso, para garantir a homogeneidade da enzima, é importante escolher um suporte inerte para o processo de imobilização e também ajustar valores corretos de temperatura e $\mathrm{pH}$ da reação para que estas influenciem positivamente.

\section{Resultados e Discussão}

Foram estudados neste trabalho a síntese com biocatálise de 3 ésteres sendo eles: valerato de etila (VE), acetato de isoamila (Al) e acetato de hexila (AH). As reações de esterificação são representadas na Figura 1.<smiles>[Y]COC(=O)OCCO</smiles>

Figura 1. Síntese de um éster genérico.

Para a reação, utilizou-se como biocatalisador a lipase de Burkholderia cepacia imobilizada em PÓS-PVA utilizando-se dois métodos de tratamento: imobilização por adsorção física e por ligação covalente.

Além desta variação foi estudado também como a porcentagem de enzima imobilizada no meio afetaria a produção dos ésteres, em que foi de $1 \%, 2 \%$ e $3 \%(\mathrm{~m} / \mathrm{v})$ de lipase imobilizada. A proporção de reagentes no meio foi também avaliada para averiguar como esta variável influenciaria no resultado final, utilizando-se razões molares de 0,1,0,3 e 0,5. O primeiro passo foi verificar a atividade lipolítica da enzima livre comparado a esta imobilizada durante $120 \mathrm{~h}$.

Tem-se que para o VE a atividade diminui com o aumento da razão molar dos reagentes e da quantidade de enzima na adsorção física, no entanto se manteve estável na ligação covalente. Os ésteres $\mathrm{Al}$ e $\mathrm{AH}$ apresentaram os mesmos comportamentos de atividade lipolítica, entretanto obtiveram rendimentos menos expressivos. Para o VE, melhores resultados foram obtidos utilizando $3 \%(\mathrm{~m} / \mathrm{v})$ de lipase na razão molar de 0,1 tanto para adsorção física quanto para ligação covalente. Sendo que $12 \mathrm{~h}$ foram suficientes para $100 \%$ de conversão deste éster, enquanto foram necessários $24 \mathrm{~h}$ para o mesmo valor nos demais ésteres.

Em relação ao $\mathrm{Al}$, a adsorção física não apresentou bons resultados em nenhuma condição, ao passo que a ligação covalente em seu melhor desempenho gerou 56\% de conversão após $9 \mathrm{~h}$ de reação empregando razão de 0,5 de reagentes e $3 \%$ de lipase imobilizada. $\mathrm{O}$ mesmo ocorreu com $\mathrm{AH}$, apresentando carência de bons resultados em adsorção física, e também apresentando apenas $26 \%$ de conversão decorridas $9 \mathrm{~h}$ nas condições de razão molar 0,5 e $3 \%$ de lipase imobilizada.

\section{Conclusões}

O VE apresentou bons resultados utilizando ambos os métodos de tratamento do suporte atingindo total conversão em $12 \mathrm{~h}$ de reação. O Al obteve resultados satisfatórios apenas na ligação covalente enquanto que a adsorção física não apresentou bons resultados. $\mathrm{O} A \mathrm{H}$ por sua vez apresentou carência de boa conversão em ambos os tratamentos de suporte e em praticamente todas as condições estudadas.

\section{Agradecimentos}

Agradecimentos ao CNPq e CAPES, além das orientadoras Giovana S. Padilha e Telma T. Franco.

\footnotetext{
${ }^{1-}$ Roberts, S. M. Biocatalysts for Fine Chemicals Synthesis, England: John Wiley \& Sons Ltda, 1999.

${ }^{2-}$ Hulig, H. Industrial enzymes and their applications. New York: John Wiley \& Sons, 1998

$3^{3}$ Solomons, T.W.G. Química Orgânica. Rio de Janeiro: Livros Técnicos e Científicos, 1983.

4- Dave, R.; Madamwar, D. Esterification in organic solvents by lipase immobilized in polymer of PVA-alginate-boric acid. Process Biochemistry, v. 41, p. $951-955,2006$
} 